\title{
Membangun Sistem Integritas Untuk Pemberantasan Korupsi Dalam Sistem Peradilan Pidana Indonesia
}

\author{
Masyhudi \\ Kejaksaan Agung Republik Indonesia \\ Jln. Sultan Hasanuddin Nomor 1 Kramat Pela Kota Jakarta Selatan \\ masyhudi1706@yahoo.com
}

Received: 19 Nopember 2019; Accepted: 23 Januari 2019; Published: 24 April 2019

DOI: 10.20885/iustum.vol26.iss1.art3

\begin{abstract}
This research aims to analyse and observe: first, the current system of corruption eradication in the Indonesia's positive law perspective; second, the strategy of the Indonesian government to eradicate the corruption in future; and third, the concept of an Integrity System to eradicate the corruption in investigations conducted by the Prosecutors, Police and KPK in Indonesia. The research method used is normative juridical legal research using a legal and conceptual approach. The results of the study showed that first, the system of corruption eradication in Indonesian positive law currently has placed $K P K$ as a leader, causing disharmony among the law enforcers; second, the Indonesian government's strategy to eradicate corruption in the future can be done through an integrity system within the scope of the KPK, the Police and the Prosecutor's Office; third, the concept of the Integrity System for corruption in investigation by the Attorney General's Office, the Police and the Corruption Eradication Commission is carried out by establishing the Integrity Court. This integrity system must be able to position the three institutions as the independent Anti-Corruption Bodies.
\end{abstract}

Keywords: Corruption crime; eradication; integrity system

\section{Abstrak}

Tujuan penelitian ini untuk menganalisis dan menemukan: pertama, sistem pemberantasan tindak pidana korupsi dalam hukum positif Indonesia saat ini; kedua, strategi pemerintah Indonesia untuk memberantas tindak pidana korupsi di masa yang akan datang; dan ketiga, konsep Sistem Integritas guna memberantas tindak pidana korupsi dalam penyidikan yang dilakukan oleh Kejaksaan, Kepolisian dan KPK di Indonesia. Metode penelitian yang digunakan adalah penelitian hukum yuridis normatif dengan menggunakan pendekatan perundang-undangan dan konseptual. Hasil penelitian menyimpulkan pertama, sistem pemberantasan tindak pidana korupsi dalam hukum positif Indonesia saat ini menempatkan KPK sebagai leader, menimbulkan ketidakharmonisan di antara para penegak hukum; kedua, strategi pemerintah Indonesia untuk memberantas korupsi di masa yang akan datang dapat dilakukan melalui sistem integritas pada lingkup KPK, Kepolisian dan Kejaksaan; ketiga, konsep Sistem Integritas tindak pidana korupsi dalam penyidikan oleh Kejaksaan, Kepolisian dan KPK dilakukan dengan membentuk Mahkamah Integritas, sistem integritas ini harus bisa memposisikan ketiga lembaga ini menjadi Badan Anti Korupsi yang independen.

Kata-kata Kunci: Tindak pidana korupsi; pemberantasan; sistem integritas 


\section{Pendahuluan}

Korupsi merupakan jenis tindak pidana yang cenderung meningkat dan sangat sulit dideteksi karena menyangkut kerjasama dengan pihak lain dan sangat mengakar. Meskipun telah diatur secara tegas dalam Undang-Undang Nomor 31 Tahun 1999 jo Undang-Undang Nomor 20 Tahun 2001 tentang Pemberantasan Tindak Pidana Korupsi (UU TPK), namun Agustina ${ }^{1}$ menjelaskan bahwa pemberantasan korupsi bukan perkara yang mudah, korupsi telah mengakar, menyebar, menjangkit, dan dipraktekkan secara sistemik. Terlebih upaya penegakan hukum belum optimal dalam mengikis korupsi.

Bentuk-bentuk pelanggaran hukum korupsi di Indonesia dalam perspektif hukum Islam adalah bisa berupa ghulul (pengkhianatan), al-ghasy (penipuan), dan risywah (suap), al-hirabah (perampasan), dan al-ghasab (penggunaan hak orang lain tanpa izin). Adapun unsur-unsur tindak pidana korupsi dalam perspektif Hukum Pidana Islam adalah adanya nas yang melarangnya, kemudian telah melakukan perbuatan yang telah menyalahi nas-nas, misalnya berbuat khiyanah/ghulul, al-ghasy (penipuan), risywah (suap), al-hirabah (perampasan), al-ghasab (penggunaan hak orang lain tanpa izin), dan yang terakhir pelakunya adalah orang sudah dapat dibebankan hukum. ${ }^{2}$

Korupsi sebagai kejahatan luar biasa adalah bentuk kejahatan yang memiliki aspek sistemik (kejahatan sistematis), terorganisir (kejahatan terorganisir), jangkauan lokus dan tempus delik tersebar luas, menyebabkan kerugian dan kesengsaraan di masyarakat, melibatkan banyak pihak dari keduanya pejabat publik dan swasta. ${ }^{3}$

Hingga saat ini penyidikan tindak pidana korupsi di Indonesia dilakukan oleh Komisi Pemberantasan Korupsi (KPK), Kepolisian dan Kejaksaan. Ketiga lembaga tersebut mempunyai kewenangan melakukan penyidikan tindak pidana korupsi. Perbedaannya adalah dasar pelaksanaannya yaitu, Kepolisian dan

\footnotetext{
${ }^{1}$ Gemalia Agustina, "Pemahaman Strukturasi atas Praktik Audit Investigatif pada Kantor Perwakilan BPKRI di Surabaya (Studi Kasus Tindak Pidana Korupsi)", artikel dalam Jurnal Ekonomi dan Bisnis, Vol. 8, No. 3, 2010, hlm. 44.

${ }^{2}$ Fazzan, "Korupsi di Indonesia dalam Perspektif Hukum Pidana Islam", artikel dalam Jurnal Ilmiah ISLAM FUTURA, Volume 14, No.2, 2015, hlm. 163.

${ }^{3}$ La Niasa, "Corruption Eradication In The Perspective Of Criminology", artikel dalam International Journal of Scientific \& Technology Research, Volume 5, No.07, 2016, hlm. 125
} 
Kejaksaan dalam penyidikannya berdasarkan pada KUHAP, sedangkan KPK dalam penyidikannya tidak hanya berdasarkan pada KUHAP, namun juga Undang-Undang Nomor 30 Tahun 2002 tentang Komisi Pemberantasan Tindak Pidana Korupsi (selanjutnya disebut UU KPK) jo.Undang-Undang Nomor 10 Tahun 2015 tentang Penetapan Peraturan Pemerintah Pengganti Undang-Undang Nomor 1 Tahun 2015 tentang Perubahan Atas Undang-Undang Nomor 30 Tahun 2002 tentang Komisi Pemberantasan Tindak Pidana Korupsi Menjadi UndangUndang (selanjutnya disebut UU KPK-Perubahan) dan UU TPK.

Dalam menjalankan kewenangan yang sama yaitu melakukan penyidikan tindak pidana korupsi, ketiga institusi tersebut secara struktural tidak mempunyai hubungan langsung dan bertanggung jawab terhadap kinerja masing-masing, Kepolisian bertanggungjawab kepada Kapolri, Kejaksaan bertanggungjawab kepada Jaksa Agung dan KPK bertanggungjawab kepada pimpinan KPK. Hal ini menunjukkan bahwa kecuali hasil operasi tangkap tangan (OTT), masing-masing institusi melakukan penanganan dan penyidikan secara tersendiri dalam lingkup institusinya. Misalnya saja kepolisian akan menangani anggotanya yang terlibat tindak pidana korupsi, demikian juga dengan kejaksaan dan KPK akan melakukan pemeriksaan sendiri bagi pegawainya yang terkena kasus korupsi.

Melihat sifatnya yang demikian, maka hukum acara tindak pidana korupsi bersifat ganda, karena di samping mengacu pada ketentuan acara pada UU TPK sebagai lex specialist, juga berorientasi pada KUHAP sebagai lex generalist. Dalam hal diperlukannya kerjasama Kepolisian, Kejaksaan dan KPK, dapat berlaku sama menentukan penanganan tindak pidana korupsi. Hal ini diatur dalam Pasal 3 ayat (1) Nota Kesepahaman Antara Komisi Pemberantasan Korupsi, Kejaksaan, dan Kepolisian Nomor: SPS-97/01-55/03/2017, Nomor: KEP-087/A/JA/03/2017, Nomor: B/27/III/2017 tanggal 29 Maret 2017.

Prakteknya, ketentuan tersebut tidak berjalan sebagaimana mestinya. Contoh terjadinya tumpang tindih penyidikan pada kasus simulator SIM, terdapat dualisme penyidikan antara KPK dan Kepolisian. Kedua pihak tersebut sama-sama melakukan penyidikan atas kasus yang sama akan tetapi dalam pelaksanaan penyidikan tersebut kepolisian tidak mau tunduk kepada UU KPK, sehingga menimbulkan konflik kewenangan penyidikan di antara kedua lembaga tersebut. 
Dalam kasus itu, KPK telah terlebih dahulu melakukan penyelidikan dan penyidikan serta menetapkan tersangkanya yaitu Irjen Polisi Djoko Susilo pada tanggal 27 Juli 2012 dengan surat Sprindik Nomor: Dik-37/01/VII/2012. Pihak Kepolisian kemudian juga menetapkan lima orang sebagai tersangka lainnya dalam kasus tersebut, yaitu Budi Susanto pada 31 Juli 2012, dan 4 tersangka lainnya Pada 1 Agustus 2012. Hal ini tentu tidak sesuai dengan ketentuan Pasal 8 ayat (1) Surat Keputusan Bersama (SKB) Kejaksaan-Kepolisian-KPK, bahwa yang seharusnya bewenang pada kasus simulator SIM tersebut adalah KPK sebagai institusi yang lebih dulu mengeluarkan surat perintah penyelidikan. Hal ini menunjukkan terdapat persoalan waktu penetapan tersebut oleh KPK. Jika KPK telah menetapkan seseorang menjadi tersangka lebih dahulu, maka Kepolisian tidak bisa menetapkan hal lain selain yang telah ditetapkan oleh KPK.

Kasus lainnya adalah penanganan sejumlah anggota Polda Jawa Barat yang bertugas di Ditreskrimum Polda Jabar karena terlibat kasus dugaan suap dari pelaku judi online. Perkara tersebut menyeret Mantan Kepala Sub Direktorat III/Jatanras Direktorat Reserse Kriminal Umum Polda Jawa Barat, yang memeras pemilik rekening terkait kasus judi online hingga mencapai Rp. 5.000.000.000,00 dan uang dolar Amerika Serikat sebesar USD 168.000 atau setara Rp. 2.000.000.000,00, yang totalnya menjadi sekitar Rp. 7.000.000.000,00. Meskipun sebenarnya penanganan perkara kasus judi online tersebut sudah ditangani Direskrimum Polda Jawa Barat semenjak 2013, namun penangananya terkesan tidak serius, karena tidak menyentuh aktor utama maupun atasan dari para pelaku yang diseret.

Bila dilihat dari hierarki struktur tata hukum di Indonesia, struktur hierarki tata hukum Indonesia diatur Pasal 7 Undang-Undang Nomor 12 Tahun 2011 tentang Pembentukan Peraturan Perundang-Undangan, struktur tata hukum Indonesia adalah:

1. Undang-Undang Dasar Negara Republik Indonesia Tahun 1945;

2. Ketepatan Majelis Permusyawaratan Rakyat;

3. Undang-Undang/Peraturan Pemerintah Pengganti Undang-Undang;

4. Peraturan Pemerintah;

5. Peraturan Presiden;

6. Peraturan Daerah, Provinsi, dan

7. Peraturan Daerah Kabupaten Kota. 
Berdasarkan struktur tata hukum di Indonesia di atas, maka jelas bahwa SKB, Kejaksaan, Kepolisian dan KPK tidak termasuk peraturan perundang-undangan di Indonesia. Oleh karena itu, SKB tersebut tidak dapat mengesampingkan UU KPK, yang jelas-jelas merupakan peraturan perundang-undangan dengan hierarki kedua setelah UUD NRI 1945.

Berdasarkan kewenangan adanya pertentangan peraturan perundangundangan serta ketidakjelasan kewenangan yang dimiliki oleh masing-masing institusi penyidik seperti pengambilalihan perkara yang sudah ditangani oleh Kepolisian dan Kejaksaan, maka ketiga institusi penyidik terjadi perbedaan pada pelaksanaan hukumnya sehingga timbul tumpang tindih dalam penyidikan, rebutan perkara, berkompetisi, saling tangkap, saling sadap di antara ketiga institusi penyidik. Konsekuensinya, timbul konflik antara institusi penyidik dan adanya disharmonisasi antar institusi penyidik. Padahal secara fungsional, walaupun fungsi dan ketentuan perundangan yang mengatur ketiga institusi berbeda, tetapi tujuannya sama yaitu penegakan hukum dalam memberantas tindak pidana korupsi.

Tumpang tindih kewenangan penyidikan tersebut sebenarnya tidak perlu terjadi, mengingat Pasal 9 UU KPK sudah mengatur bahwa KPK berwenang mengambil alih kewenangan penyidikan tindak pidana korupsi yang sedang dilakukan oleh penegak hukum lainnya seperti kepolisian dan kejaksaan. Adanya Surat Keputusan Bersama nyatanya tidak menyelesaikan adanya persoalan dalam pemberantasan tindak pidana korupsi.

Berdasarkan uraian di atas, dapat disimpulkan bahwa Pasal 9 dan Pasal 11 huruf a UU KPK, yang menegaskan bahwa yang berwenang melakukan penyidikan terhadap tindak pidana korupsi yang melibatkan aparat penegak hukum, penyelenggara negara dan orang lain yang ada kaitannya dengan tindak pidana korupsi yang dilakukan oleh aparat penegak hukum atau penyelenggara negara adalah KPK (das sollen), namun pada kenyataannya masih terjadi benturan dalam pelaksanaannya, dan tumpang tindih kewenangan antara kejaksaan, kepolisian dan KPK dalam penanganan tindak pidana korupsi (das sein). Berdasarkan kesenjangan antara das sollen dengan das sein tersebut, khususnya dalam rangka pemberantasan tindak pidana korupsi di Indonesia, maka peneliti 
mencoba menawarkan pembangunan sistem integritas pada Kejaksaan, Kepolisian dan KPK dalam proses pemberantasan korupsi di Indonesia.

\section{Rumusan Masalah}

Rumusan masalah dalam penelitian ini sebagai berikut: Pertama, bagaimana sistem pemberantasan tindak pidana korupsi dalam hukum positif Indonesia saat ini? Kedua, bagaimana strategi pemerintah Indonesia untuk memberantas tindak pidana korupsi di masa yang akan datang? Ketiga, bagaimana konsep Sistem Integritas guna memberantas tindak pidana korupsi dalam penyidikan yang dilakukan oleh Kejaksaan, Kepolisian dan KPK di Indonesia?

\section{Tujuan Penelitian}

Tujuan penelitian ini untuk mengevaluasi, membangun, mengkritisi dan menemukan: pertama, sistem pemberantasan tindak pidana korupsi dalam hukum positif Indonesia saat ini; kedua, strategi pemerintah Indonesia untuk memberantas tindak pidana korupsi di masa yang akan datang; dan ketiga, konsep Sistem Integritas guna memberantas tindak pidana korupsi dalam penyidikan yang dilakukan oleh Kejaksaan, Kepolisian dan KPK di Indonesia.

\section{Metode Penelitian}

Penelitian ini adalah penelitian hukum normatif dengan pendekatan statute approach (pendekatan perundang-undangan) dan conceptual approach (pendekatan konseptual). Pendekatan perundang-undangan dilakukan dengan menelaah peraturan perundang-undangan yang bersangkut paut dengan permasalahan (isu hukum) yang sedang dihadapi. Pendekatan konseptual beranjak dari pandanganpandangan dan doktrin-doktrin yang berkembang di dalam Ilmu Hukum untuk dijadikan pijakan dalam membangun argumentasi hukum ketika menyelesaikan isu hukum yang dihadapi. Pandangan/doktrin akan memperjelas ide-ide dengan memberikan pengertian-pengertian hukum, konsep hukum, maupun asas hukum yang relevan dengan permasalahan. ${ }^{4}$ Data dan bahan-bahan hukum yang digunakan mengacu pada data sekunder yang mencakup bahan-bahan hukum

${ }^{4}$ Peter Mahmud Marzuki, Penelitian Hukum, Kencana Prenida Media, Jakarta, 2011, hlm. 34. 
primer, terdiri dari peraturan perundang-undangan, jurisprudensi, dan konvensikonvensi yang terkait dengan sistem integritas nasional, khususnya dalam pemberantasan korupsi, serta bahan hukum sekunder dan tersier. ${ }^{5}$ Namun demikian, untuk mengetahui perkembangan yang terjadi dalam praktek pemberantasan korupsi, penelitian ini juga menggunakan data primer, yaitu data yang diperoleh langsung dari responden atau narasumber yang terkait dengan upaya pembentukan sistem integritas dalam pemberantasan korupsi di Indonesia.

Pengumpulan data dilakukan dengan penelusuran literature (library research), baik secara ekstensif maupun intensif, yang bertujuan untuk mengkaji, meneliti, dan menelusuri data sekunder, berupa bahan-bahan hukum. ${ }^{6}$ Bahan-bahan hukum bersifat normatif-prespektif, digunakan terutama untuk mengkaji permasalahan hukum yang terkait dengan substansi peraturan hukum positif (ius constitutum) yang sifatnya mengatur tentang pembangunan konsep sistem integritas dalam pemberantasan korupsi di Indonesia, berdasarkan kekuatan mengikatnya diklasifikasikan sebagai bahan hukum primer, bahan hukum sekunder dan bahan hukum tersier. 7 Teknik analisis data yang digunakan merupakan analisis yuridis yaitu analisis yang mendasarkan pada teori-teori, konsep dan peraturan perundang-undangan.

\section{Hasil Penelitian dan Pembahasan}

\section{Sistem Pemberantasan Tindak Pidana Korupsi dalam Hukum Positif Indonesia Saat Ini (Ius Constitutum)}

Politik hukum pembentukan lembaga anti rasuah di Indonesia berawal dari mandat konstitusional sebagaimana termaktub di dalam Ketetapan MPR RI No. XI/MPR/1998 tentang Penyelenggara Negara yang Bersih dan Bebas Korupsi, Kolusi dan Nepotisme. Atas dasar mandat tersebut maka, Pemerintah menindaklanjuti pembentukan Undang-Undang Nomor 28 Tahun 1999 tentang Penyelenggara Negara yang Bersih dan Bebas Korupsi, Kolusi dan Nepotisme serta UU TPK yang mengamanatkan pembentukan KPK. Pembentukan kelembagaan KPK bukan dimaksudkan untuk mengambil alih tugas pemberantasan korupsi

\footnotetext{
${ }^{5}$ Ronny Hanitijo Soemitro, Metode Penelitian Hukum dan Jurumetri, Ghalia Indonesia, Jakarta, 2008, hlm. 97. ${ }^{6}$ Bambang Waluyo, Penelitian Hukum Dalam Praktik, Penerbit Sinar Grafika, Jakarta, 2001, hlm. 18.

${ }^{7}$ Soerjono Soekanto, Pengantar Penelitian Hukum, Universitas Indonesia Press, Jakarta, 2006, hlm. 52.
} 
dari lembaga-lembaga yang ada sebelumnya. Penjelasan Undang-Undang menyebutkan KPK sebagai trigger mechanism, yang berarti mendorong atau sebagai stimulus agar upaya pemberantasan korupsi oleh lembaga-lembaga yang telah ada sebelumnya menjadi lebih efektif dan efisien. ${ }^{8}$

Institusi yang memiliki kewenangan dalam melakukan pemberantasan tindak pidana korupsi di Indonesia adalah Kepolisian, KPK dan Kejaksaan. Dalam perjalanannya KPK diberi kewenangan untuk mengambil alih penyidikan yang dilakukan oleh kepolisian maupun kejaksaan. Jika melihat tugas dan kewenangan KPK yang sangat besar dapat disimpulkan bahwa KPK ini memiliki kendali utama dalam rangka pemberantasan tindak pidana korupsi. Permasalahan yang timbul adalah adanya kewenangan yang sama dengan kepolisian dan kejaksaan mengenai penyidikan yang juga memiliki kewenangan untuk menyidik tindak pidana korupsi, sehingga potensial menimbulkan tumpang tindih kewenangan.

Ditinjau dari perspektif elemen-elemen sistem hukum dari Friedman, khususnya terhadap elemen struktur yang menyangkut kelembagaan, maka lembaga penegak hukum tindak pidana korupsi dalam hal ini adalah Kepolisian, KPK dan Kejaksaan. Menurut Lawrence M. Friedman, tentang elemen-elemen sistem hukum diuraikan sebagai berikut: (i) structure (tatanan kelembagaan dan kinerja lembaga); (ii) substance (materi hukum); (iii) legal culture (budaya hukum). ${ }^{9}$ Dalam rangka untuk meningkatkan efektivitas penegakan hukum dalam pemberantasan korupsi, penyempurnaan kedudukan dan peranan elemen-elemen struktur hukum atau badan-badan penegak hukum sesuai dengan tugas, fungsi, dan wewenang masing-masing harus dipercepat peningkatan kemampuannya maupun kewibawaan peradilan disertai upaya untuk membina sikap aparat penegak hukum yang memiliki keahlian, jujur, tegas, adil, bersih, dan berwibawa.

Isu yang sering muncul adalah menyangkut sumber daya manusia (SDM), selama ini dipandang profesionalitas aparat penegak hukum. Hukum dianggap masih belum memenuhi harapan masyarakat pencari keadilan, terbukti dengan masih banyak masyarakat yang merasa rasa keadilannya terabaikan oleh aparat

\footnotetext{
${ }^{8}$ Cindy Rizka Tirzani Koesoemo, ”Eksistensi Komisi Pemberantasan Korupsi (KPK) dalam Penanganan Penyidikan dan Penuntutan Tindak Pidana Korupsi”, artikel dalam Lex Crimen Vol. VI, No. 1, 2017, hlm. 63.

${ }^{9}$ Lawrence M. Friedman, A History of American Law, Simon and Schuster, New York, 2013, hlm. 1
} 
penegak hukum. Di samping itu, KPK melalui UU KPK telah diberi kewenangan khusus untuk melakukan penyelidikan, penyidikan, dan penuntutan sekaligus. Selanjutnya dengan UU No. 2 Tahun 2002 tentang Kepolisian Negara Republik Indonesia, Kepolisian juga diberikan kewenangan dalam penyelidikan dan penyidikan, tetapi tidak untuk melakukan penuntutan. Kewenangan yang ada pada KPK dan Kepolisian tersebut, diharapkan dapat mensinergikan upaya-upaya pemberantasan korupsi secara lebih progresif, namun ternyata berimplikasi pada akuntabilitas publik dan ambiguitas kewenangan yang pada akhirnya menimbulkan sengketa kewenangan dan benturan kepentingan yang sebenarnya hanya didasari oleh egoisme sektoral aparat penegak hukum. Sejatinya kalau dikembalikan pada hakikat kewenangan KPK dan Kepolisian yang sama-sama berkeinginan untuk memberantas korupsi, dapat dilakukan secara bersama-sama dengan saling membantu dan memperkuat lembaga untuk tujuan yang sama. Apabila yang terjadi adalah sebaliknya, yaitu saling berebut kasus, maka akan terjadi kendala-kendala penyidikan di lapangan yang menyebabkan gagalnya penuntutan terhadap suatu tindak pidana korupsi, dan akan sulit untuk menentukan institusi mana yang harus bertanggung-jawab atas kegagalan tersebut dan bagaimana pertanggung-jawabannya kepada publik.

Pada substansi hukum sering terjadi ambiguitas dan duplikasi, rumusan pasal sering kali menimbulkan ragam penafsiran yang berakibat pada keraguan dalam penerapannya, bahkan juga dicampurkan dengan muatan politis dari kasus yang sedang ditangani. Demikian pula terhadap institusi KPK, Kepolisian, dan Kejaksaan dalam hal kewenangan di bidang penyidikan, apabila tidak ditafsirkan secara tepat dan tanpa ada pengaruh muatan politisnya, seharusnnya dapat diperoleh kepastian hukum dalam penanganan kasus dugaan tindak pidana korupsi tersebut. Oleh karena itu, dibutuhkan kecerdasan dan ketulusan aparat dalam memaknai substansi dari peraturan yang mengatur kewenangan tersebut, sehingga tidak timbul duplikasi dan ambiguity terhadap kasus yang sedang ditangani.

Faktanya, sejak 2006 tercatat adanya kemunduran di bidang penegakan hukum tindak pidana korupsi yang ditandai dengan: pertama, munculnya perlawanan para koruptor melalui saluran uji materiil terhadp UU KPK ke Mahkamah Konstitusi (MK), khususnya ketentuan Pasal 53-62 tentang keberadaan 
pengadilan TIPIKOR yang dianggap bertentangan dengan Pasal 24 ayat (3) UUD 1945. Pemohon uji materiil adalah para terdakwa korupsi di KPU yang menilai bahwa pengadilan Tipikor yang dibentuk melalui Pasal 53 UU KPK seharusnya diatur dalam UU tersendiri, sehingga hak-hak konstitusional pemohon telah dilanggar karena diperiksa dan diadili oleh badan peradilan yang tidak berwenang. Kedua, masih terlihat adanya "tebang pilih", di mana kasus korupsi yang diproses selama ini masih pada tataran kasus yang kecil, padahal seharusnya yang juga dijadikan target adalah koruptor kelas kakap.

Ditinjau dari budaya hukum, saat ini telah terjadi degradasi budaya hukum yang ditandai dengan meningkatnya apatisme seiring dengan menurunnya tingkat apresiasi masyarakat baik kepada substansi hukum maupun kepada struktur hukum. Pada pemberantasan tindak pidana korupsi, sering diperlihatkan kepada masyarakat akan adanya penegakan hukum tindak pidana korupsi terjadi diskriminasi ataupun "tebang pilih" serta tidak transparannya aparat dalam menangani perkara dugaan tindak pidana korupsi yang dapat menyebabkan kepercayaan masyarakat rendah untuk mematuhi hukum.

Hal yang penting dalam budaya hukum ini khususnya terhadap kasus-kasus dugaan korupsi adalah pemahaman penuh dan komprehensif atas nilai-nilai yang menopang hukum khususnya terkait dengan pengaturan pemberantasan tindak pidana korupsi, sehingga akan meningkatkan kesadaran hukum setiap individu baik sebagai aparat maupun masyarakat umum, terhadap hak dan kewajibannya. Dalam pemberantasan korupsi, hanya akan dapat tercapai secara maksimal jika masyarakat mau mengakui nilai-nilai yang akan dan perlu ditegakkan, serta mau menilai dan menyadari bahwa sistem yang ada adalah adil dan proses hukumnya diterapkan sebagaimana mestinya. Kenyataannya, persepsi korupsi dapat meningkat ketika publik memahami bahwa aturannya ada tetapi diabaikan, tidak diterapkan secara adil kepada publik, atau bahwa mereka mendukung kepentingan khusus. Aturan yang mendorong transparansi mungkin tidak berarti di mana prosedur pengambilan keputusan yang rumit dan negosiasi yang tidak jelas terjadi, atau hanya meningkatkan kurangnya kepercayaan publik terhadap lembaga pemerintah jika aturan tersebut 
tidak ditegakkan secara adil dan memadai. ${ }^{10}$ Apabila hukum dirasakan telah responsif dan aspiratif, para pemimpin negara telah pula memberikan teladan mentaati dan menghargai hukum, memberikan saluran keadilan yang dapat memuaskan masyarakat, maka dengan sendirinya masyarakat akan lebih menghargai hukum. Faktor-faktor inilah yang akan memberi sumbangan besar dalam membentuk budaya hukum masyarakat, di samping itu juga dapat dilakukan melalui konsep penyadaran hukum dengan pendekatan dialogis dan demokratis.

Dalam membangun tata kelola lembaga penegak hukum tindak pidana korupsi di Indonesia, perlu pendekatan check and balances, yaitu suatu pendekatan yang menekankan adanya hubungan yang saling terkait dan saling membatasi antar organ penyelenggara kekuasaan Negara sebagaimana ditentukan oleh konstitusi. KPK, Kepolisian, dan Kejaksaan seharusnya sejajar dan saling mengawasi untuk secara bersinergi melakukan kewenangannya dalam memberantas tindak pidana korupsi. Hal ini dapat dilakukan melalui pemahaman sinergisitas yaitu kesadaran akan saling menguatkan lembaga untuk satu tujuan yang sama dengan saling bekerjasama secara serasi dengan dilandasi rasa saling percaya, hormat menghormati dan keterbukaan berdasar peraturan perundangundangan. Di samping itu juga dengan mengedepankan efektifitas dan efisiensi dengan memaksimalkan tugas dan fungsinya.

Selanjutnya, tolok ukur yang dapat digunakan untuk membangun tata kelola lembaga penegak hukum tindak pidana korupsi adalah dengan indikator keberhasilan dan manfaat yang dapat diperoleh masyarakat yaitu efektivitas dan efisiensi. Apabila KPK, Kepolisian, dan Kejaksaan tidak memenuhi tolok ukur (efektivitas dan efisiensi), eksistensinya justru menimbulkan terjadinya tumpangtindih fungsi dan kewenangan antara ketiganya.

Pada saat melakukan penyidikan sebuah kasus korupsi, penyidik kepolisian mempunyai wewenang penuh untuk melakukan pengusutan. Untuk itu, selama penyidik kepolisian profesional dan proporsional, KPK tidak dapat melakukan tindakan lain selain pihak penyidik kepolisian. Dalam undang-undang, KPK dapat melakukan tindakan lain apabila ada pengaduan dari masyarakat terhadap proses

10 Mel D. Powell, "International Efforts to Combat Corruption” Prociding of 2017 Annual Conference American Society for Public Administration Atlanta, Georgia, Vol.17, No.21, 2017, hlm. 1. 
pengusutan tersebut. Pengaduan itu bisa disebabkan karena penanganan kasus yang terlalu bertele-tele dan tidak jelas sehingga muncul dugaan terjadi kesepakatan-kesepakatan tidak proporsional antara penyidik dengan tersangka, atau muncul dugaan manipulasi terhadap pengusutan kasus sehingga menyebabkan aktor utama korupsi terhindar dari hukuman.

Selain dengan pihak kepolisian, KPK juga memiliki hubungan dengan kejaksaan. Hubungan ini karena KPK juga memiliki wewenang untuk melakukan penuntutan. Tugas penuntutan selama ini menjadi ranah dari kejaksaan. Pasal 30 ayat (1) a Undang-Undang No. 16 Tahun 2004 tentang Kejaksaan menyatakan, bahwa Kejaksaan mempunyai tugas dan wewenang melakukan penuntutan bidang pidana. Tentu saja sebagai lembaga yang juga memiliki wewenang melakukan penuntutan, KPK perlu tenaga-tenaga dari kejaksaan untuk melakukan penuntutan.

Berdasarkan pembahasan yang telah dikemukakan di atas, maka dapat disimpulkan bahwa sistem pemberantasan tindak pidana korupsi dalam hukum positif Indonesia saat ini (ius constitutum) yang menempatkan KPK sebagai leader dalam pemberantasan korupsi justru menimbulkan ketidakharmonisan para penegak hukum antara KPK, Kepolisian dan Kejaksaan. Hal ini menunjukkan strategi pemberantasan korupsi di Indonesia saat ini masih belum efektif dan optimal, yang akibatnya adalah korupsi masih terus terjadi di Indonesia dengan situasi yang semakin massive.

\section{Strategi Penanganan Tindak Pidana Korupsi di Masa yang Akan Datang (Ius Constituendum)}

Jelas bahwa korupsi adalah salah satu bentuk perampasan rakyat yang seharusnya tanpa adanya korupsi rakyat dapat hidup lebih sejahtera. Justru karena korupsi, kesejahteraan orang-orang yang miskin terperangkap dalam kemiskinan. Padahal, kemiskinan masih menjadi tantangan besar yang harus dihadapi oleh rakyat Indonesia. Huguette Labelle menyatakan, bahwa "dalam dekade tengah kemajuan negara-negara yang telah berhasil menelurkan undang-undang dan peraturan antikorupsi, korupsi masih membatasi jutaan orang dalam kemiskinan".11

11 Abd. Rachman A., "Policy Analysis and Educational Strategy for Anti Corruption in Indonesia and Singapore", artikel dalam International Journal of Asian Social Science, Vol.5, No.11, 2015, hlm. 612-613. 
Indonesia telah memiliki cukup banyak peraturan perundangan berkaitan dengan korupsi. Namun, pemberantasan korupsi di Indonesia lebih mengutamakan pada aspek penindakan (ex post facto) dibandingkan dengan aspek pencegahan (ex ante). Di samping beberapa strategi utama tersebut di atas, pemerintah Indonesia juga melakukan upaya-upaya khusus untuk memberantas korupsi antara lain melalui: (1) reformasi birokrasi yang menekankan keterbukaan, kesempatan yang sama dan transparansi dalam rekrutmen pegawai negeri, kontrak, retensi dan proses promosi termasuk remunerasi dan diklat; (2) reformasi sektor pengadaan barang dan jasa yang merupakan sektor yang paling rentan dengan praktik-praktik korupsi; (3) menetapkan peraturan perundang-undangan mengenai anti pencucian uang; dan (4) Perjanjian ekstradisi dengan beberapa negara antara lain yakni dengan Malaysia (1975), Filipina (1976), Thailand (1978), dan Singapura (2007).12

Walaupun berbagai upaya telah dilakukan, namun pemberantasan korupsi di Indonesia seperti tidak tahu arah dan jalan di tempat. Kegagalan dalam memberantas korupsi dikarenakan beberapa kelemahan dalam strategi yang diterapkan pemerintah, antara lain: Pertama, strategi sistem, yaitu belum terbentuknya sistem penanganan korupsi yang terintegrasi, belum terwujudnya sistem pengembalian aset (asset recovery) atas hasil-hasil kejahatan korupsi, belum terbentuknya sistem kerjasama penegak hukum yang terkait dengan penanganan korupsi. Kedua, strategi regulasi, yaitu belum terciptanya harmonisasi perundangundangan yang komprehensif. Ketiga, strategi institusional, yaitu terjadinya tumpang tindih (overlapping) kewenangan penanganan kasus korupsi, belum optimalnya koordinasi antara institusi-institusi yang menangani kasus korupsi, dan tidak adanya prioritas penanganan kasus kasus korupsi.

Berdasarkan pembahasan sebelumnya Indonesia memang masih menghadapi permasalahan dan kendala penegakan hukum meliputi aspek koordinasi antar instansi, khususnya dalam sistem peradilan pidana. Hal ini disebabkan masing-masing lembaga penegak hukum menjalankan tugas dan

12 Ibrahim S. Assegal, A Gloomy Picture of the Attempts to Eradicate Corruption: Reflection of the Policies, Laws and Institutions of Corruption Management in Indonesia, 1969-2001, In Richard Holloway, Stealing from the People, 2012, hlm. 16 
tanggungjawab yang berbeda sesuai ketentuan yang berlaku, yaitu Undang-Undang No. 16 Tahun 2004 tentang Kejaksaan Republik Indonesia, Undang-Undang No. 48 Tahun 2009 tentang Kekuasaan Kehakiman dan Undang-Undang No. 46 Tahun 2009 tentang Pengadilan Tindak Pidana Korupsi, UU KPK-Perubahan dan UndangUndang No. 02 Tahun 2002 tentang Kepolisian Republik Indonesia.

Kejaksaan khususnya, memiliki kedudukan sentral dalam upaya penegakan hukum sebagai salah satu subsistem dari sistem peradilan pidana di Indonesia. Sistem peradilan pidana (Criminal Justice System) di Indonesia hanya mengenal 4 (empat) subsistem, yaitu: (1) Kepolisian, (2) Kejaksaan, (3) Pengadilan dan (4) Lembaga Pemasyarakatan. Tugas dan kewenangan kejaksaan dalam lingkup peradilan semakin dipertegas dalam Undang-Undang Nomor 8 Tahun 1981 tentang Hukum Acara Pidana (KUHAP), di mana posisi kejaksaan merupakan lembaga penuntutan dalam sistem peradilan pidana. Dalam perkara tindak pidana korupsi, kejaksaan diberikan kewenangan untuk menyidik perkara tersebut. Kejaksaan dianggap sebagai pengendali proses perkara dikarenakan hanya institusi kejaksaan yang dapat menentukan suatu kasus dapat dilimpahkan ke pengadilan atau tidak, di samping juga merupakan satu-satunya institusi pelaksana putusan pidana.

Pada aspek penyidikan dan penuntutan yang semula menjadi kewenangan kepolisian dan kejaksaan sepertinya telah memberikan peluang akan tidak terbatasnya kewenangan KPK. Akan tetapi pembagian dan pemisahan kewenangan tampak kurang konsisten dan berpeluang membuat kevakuman hukum dalam mensinergikan fungsi kerjasama antara KPK dan pihak Polisi dalam konteks penyelidikan dan penyidikan, sehingga berdampak pada timbulnya kecemburuan di lembaga penegak hukum yang lebih dulu berperan dan sistem pidana Indonesia, juga akan berpengaruh pada proses deligitimisasi institusi penegak hukum. Hal ini didasarkan pada alasan bahwa KPK sebagai institusi terobosan terhadap kemandegan kredibilitas penegak hukum, yang sampai hari ini tidak dibatasi pemberlakuannya.

Oleh karena itu, pembentukan KPK dalam pelaksanaannya terbentur banyak kendala. Kendala tersebut antara lain, KUHAP yang mengatur bahwa proses 
penyidikan dan penuntutan merupakan tugas Kejaksaan. Akan tetapi, Pasal 8 ayat (2) UU KPK mengatur bahwa KPK berwenang juga mengambil alih penyidikan atau penuntutan terhadap pelaku tindak pidana korupsi yang sedang dilakukan oleh kejaksaan. Di sisi lain, Kejaksaan juga mempunyai kewenangan sebagai eksekutor terhadap penanganan perkara tindak pidana korupsi yang ditangani oleh KPK, dilihat dari hal tersebut maka KPK dengan Kejaksaan akan selalu mempunyai hubungan koordinasi, baik dalam penanganan perkara korupsi maupun dalam hal eksekusi terhadap perkara yang ditangani oleh KPK, tetapi dengan adanya dualisme kewenangan tersebut maka menjadi suatu hal yang selalu menjadi perdebatan.

Berdasarkan pembahasan yang telah dikemukakan di atas, maka dapat disimpulkan bahwa strategi pemerintah Indonesia untuk mencegah tindak pidana korupsi di masa yang akan datang (ius constituendum) dapat dilakukan melalui sistem integritas pada lingkup KPK, Kepolisian dan Kejaksaan. Sistem integritas antara ketiga penegak hukum ini menempatkan KPK, Kepolisian dan Kejaksaan sebagai aparat penegak hukum dalam pemberantasan korupsi yang mempunyai kedudukan dan kewenangan yang sama saling bersinergi satu sama lainnya, serta dibebankan dengan adanya tanggungjawab kepada masing-masing institusi secara berimbang agar masing-masing institusi menjadi pihak yang diawasi sekaligus pihak yang mengawasi sebagai pihak yang memantau dan pihak yang dipantau dalam pemberantasan korupsi di masa yang akan datang, sehingga khusus terhadap ketiga institusi penegak hukum pidana korupsi terjadi chek and balances.

\section{Sistem Integritas dalam Pemberantasan Tindak Pidana Korupsi di Tingkat Penyidikan oleh Kejaksaan, Kepolisian dan KPK di Indonesia \\ Hakekat Sistem Integritas Nasional}

Pelembagaan Sistem Integritas Nasional (SIN) perlu memastikan bahwa sistem integritas menjadi sistem formal baik di lingkungan organisasi maupun dalam lingkup nasional. Setiap individu dan organisasi mengimplementasikan nilai-nilai luhur bangsa Indonesia dalam kehidupan sehari-hari termasuk dalam menjalankan tugas dan fungsinya di masyarakat, sehingga tujuan organisasi maupun pribadi tercapai dengan cara-cara yang berakhlak mulia. Nilai-nilai kejujuran, kedisiplinan, keadilan, transparan, tanggungjawab, keteladanan dan 
mengutamakan kepentingan umum, kepentingan bangsa dan negara di atas kepentingan pribadi dan golongan harus diimplementasikan di Kementerian/ Lembaga, organisasi lainnya, dan Pemerintah Daerah. Sistem Integritas Nasional (SIN) akan berhasil jika keberadaan pemimpin di berbagai lini Institusi mampu mempengaruhi lingkungannya untuk mencapai tujuan Institusi. Dalam konteks ini pemimpin berperan sebagai contoh, teladan bagi lingkungan sekitarnya. Sistem Integritas Nasional (SIN) juga akan berhasil jika ada komunikasi dan kerjasama yang efektif di masing-masing institusi untuk membangun akuntabilitas horizontal. Program-program di Kementerian/Lembaga terintegrasi dan berjalan beriringan dengan Sistem Integritas Nasional dan yang tidak kalah penting, agar Sistem Integritas Nasional (SIN) berhasil adalah keberadaan lingkungan yang kondusif, di mana diperlukan upaya untuk menciptakan kondisi yang menjunjung tinggi integritas, baik di level institusi maupun individu. ${ }^{13}$

Hakekat atau esensi sistem integritas nasional ini akan dijabarkan dan dielaborasi ke dalam beberapa sub-pembahasan: (i) konsep dasar; (ii) tujuan, tugas dan fungsi elemen-lemen pilar kelembagaan yang dilibatkan dalam pemberantasan korupsi.

\section{1) Konsep Dasar}

Sistem integritas nasional ini merupakan sistem interaksi antar komponen atau pilar-pilar kelembagaan yang komprehensif, yang memungkinkan setiap komponennya dapat melakukan pengawasan (control) dalam menjaga keseimbangan (check and balances), mengawasi dan diawasi, memantau dan dipantau guna mencapai tujuan bersama.

\section{2) Tujuan dan Fungsi Elemen}

Secara operasional, sistem integritas nasional ini hanya dapat dijalankan dengan baik, apabila semua komponen atau elemen-elemen pilar kelembagaan ini dapat berinteraksi dengan baik dan produktif. Seluruh komponen atau elemen pilar kelembagaan tersebut harus mengemban tugas dan fungsi yang proporsional sesuai dengan eksistensi, kapasitas dan profesionalitas masing-masing.

13 A. H. Rahadian, "Sistem Integritas Nasional sebagai Kebijakan Mencegah dan Memberantas Korupsi di Indonesia”, artikel dalam Prosiding Seminar STIAMI, Volume I, No. 02, 2014, hlm.10. 


\begin{tabular}{|c|c|}
\hline Pilar-pilar kelembagaan & Tugas dan Fungsi \\
\hline Eksekutif & Mengelola sumber daya untuk kepentingan public \\
\hline Legislatif/Parlemen & $\begin{array}{l}\text { Merumuskan kebijakan dan aturan kolektif yang } \\
\text { sejalan dengan mandat konstitusi }\end{array}$ \\
\hline $\begin{array}{l}\text { Komisi Anggaran Belanja } \\
\text { (legislatif) }\end{array}$ & $\begin{array}{l}\text { Merumuskan dan menyusun anggaran belanja } \\
\text { Negara }\end{array}$ \\
\hline Auditor-Negara & Laporan pada public \\
\hline Institusi Pelayanan Publik & Melayanipublic \\
\hline Peradilan & Mendistribusikan keadilan secara Independen \\
\hline Media & $\begin{array}{l}\text { Memperoleh dan mendistribusikan informasi } \\
\text { yang benar }\end{array}$ \\
\hline Masyarakat sipil & $\begin{array}{l}\text { Kebebasan berbicara dan berserikat dalam } \\
\text { melakukan respondan pengawasan }\end{array}$ \\
\hline Ombudsman & Melakukan pengawasan dalam pelayanan public \\
\hline $\begin{array}{l}\text { Lembaga anti-korupsi/ } \\
\text { pengawas }\end{array}$ & $\begin{array}{l}\text { Menegakkan aturan dan perundang-undangan } \\
\text { khususnya dalam pemberantasan korupsi }\end{array}$ \\
\hline Sektor swasta & $\begin{array}{l}\text { Akselerator pertumbuhan dan pemerataan } \\
\text { pembangunan }\end{array}$ \\
\hline $\begin{array}{l}\text { Multi National } \\
\text { Corporation (MNC) }\end{array}$ & $\begin{array}{l}\text { Akselerator pertumbuhan dan pemerataan } \\
\text { pembangunan Ekonomi }\end{array}$ \\
\hline
\end{tabular}

Seluruh tugas dan fungsi elemen-elemen sistem integritas atau pilar-pilar kelembagaan tersebut harus berinteraksi dengan menjalankan fungsi masingmasing secara profesional. Interaksi yang produktif ini hanya dapat dilakukan apabila semua komponen berinteraksi atas dasar prinsip kebenaran, kepercayaan, kesetaraan, dan kejujuran antar lembaga.

\section{Fondasi Sistem Integritas Nasional dalam Pemberantasan Korupsi}

Dalam bagian ini, penulis akan mengelaborasi beberapa landasan atau fondasi filosofis dan teoritis dari pembentukan atau pembangunan system integritas nasional dalam pemberantasan korupsi.

\section{1) Fondasi Filosofis dan Teoritik}

Secara teoritik, hukum harus diabadikan untuk memelihara ketertiban dan keadilan yang dapat menjamin sustainabilitasnya dalam kehidupan bersama. Hal ini diperlukan sebagai prasyarat kehidupan bersama dapat berjalan dengan baik sehingga semua anggota masyarakat dapat bertransformasi bersama menuju tatanan sosial yang ideal (Ideal State of Sosial Order). Guna mencapai tujuan bersama yaitu tatanan sosial yang ideal, maka semua sub-sub sistem dalam kehidupan 
bersama, seperti budaya, sosial, politik dan ekonomi harus diabadikan untuk membantu masyarakat mencapai ideal state of sosial order.

\section{2) Fondasi Normatif}

Fondasi normatif dalam pembentukan sistem integritas nasional ini berkaitan dengan dasar validitas keberadaan sistem integritas. Dalam hal ini eksistensi lembaga integritas nasional ini harus didasarkan atas norma yang valid. Secara teoritik, validitas norma itu harus dibentuk dan bersandar pada satu karakteristik tunggal, yaitu adanya self-explanatory. Self-explanatory ini adalah kemampuan norma itu untuk menjelaskan kepada publik bahwa ia benar dalam dirinya sendiri. ${ }^{14}$

\section{Model Sistem Integritas Nasional dalam Pemberantasan Korupsi}

Dalam kaitannya dengan hukum, konsep di atas mensyaratkan hukum dan elemen-elemennya sebagai instrument untuk mengasuh, mendidik dan membina masyarakat menuju cita-cita bersama. Secara akal sehat (common sense), cita-cita bersama itu hanya dapat diwujudkan jika masyarakat memiliki semangat, spirit, energi dan tindakan yang harmoni dan saling melengkapi, bukan saling menegasikan. Untuk itu, semua masyarakat harus berada dalam keutuhan. Secara logis, keutuhan ini hanya dapat dicapai melalui interaksi yang seimbang. Dalam bahasa hukum, keseimbangan ini adalah keadilan. Dengan demikian, keadilan seharusnya diabadikan untuk memelihara keutuhan yang dapat menjamin sustainabilitas kehidupan bersama. ${ }^{15}$

\section{1) Sistem Interaksi Kelembagaan}

Secara teoritik, suatu entitas atau organisma hidup, sekecil apapun, ia memiliki identitas. Identitasnya diindikasikan oleh kehidupannya atau sustainabilitasnya. Entitas dikatakan mengalami kematian apabila ia tidak memiliki identitas. Dalam perspektif teori sistem, kehidupannya itu adalah akibat atau produk dari berinteraksinya antar komponen dalam yang menyangga

\footnotetext{
${ }^{14}$ Jaap Hage, Studies in Legal Logic, Law and Philosophy Library, Springer, Meta-juridica Department, University of Maastricht, 2011, hlm. 33-40.

${ }^{15}$ Hayyan ul Haq, "Legal Instruments for an Optimal Utilization of Information and Technology Under the Intellectual Property Regime: A Study on the Implication of the Creator and Inventor Doctrine for the Utilization of Intellectual Products Through Technology Transfer for the Greatest Benefit of People in Indonesia", Disertasi Utrecht University, The Netherlands, 2011; Libat juga: Hayyan ul Haq, "Strengthening Philosopical and Axiological Legal Framework of the Corporate Sosial Responsbility Regime in Indonesia", in Tineke Lambooy, et.al., Corporate Sosial Responsbility, Konstitute, Jakarta, 2013.
} 
kehidupan entitas tersebut. Hal terpenting dalam hal ini adalah bagaimana menciptakan dan menjaga kualitas interaksi yang bermakna sehingga output atau hasil dari interaksi antar komponen itu dapat memberikan kontribusi yang menjamin sustainabilitas dan kualitas kehidupan.

Begitu pula dalam lembaga atau organisasi, khususnya lembaga dalam sistem integritas nasional, guna mempertahankan sustinabilitasnya, ia mensyaratkan adanya kualitas interaksi yang baik antar komponen kelembagaan. Berdasarkan pertimbangan tersebut, sistem integritas nasional yang dibahas dalam penelitian ini juga menekankan pentingnya kualitas interaksi yang bermakna, dan yang produktif.

\section{2) Sistem dan Mekanisme Kerja Operasional}

Semua komponen sistem integritas nasional berinteraksi dan bekerjasama berdasarkan prinsip koordinatif, bukan sub-ordinatif. Masing masing pilar kelembagaan memiliki hak dan kewenangan yang proporsional untuk dapat mengemban amanah yang dibebankan kepadanya. Pola hubungan yang koordinatif antar pilar lembaga integritas nasional ini memungkinkan masingmasing lembaga melakukan pengawasan dan siap untuk melakukan pemantauan dan siap dipantau dalam melaksanakan tugas dan kewajiban masing-masing.

Peraturan atau undang-undang ini dapat mengintegrasikan semua undangundang yang bersifat sektoral dalam penegakan hukum pemberantasan korupsi. Jadi ke depan, tidak ada lagi UU Kepolisian, Kejaksaan, (yang tunduk pada KUHAP, maupun UU KPK). Semuanya difusi menjadi satu Undang-Undang Sistem Integritas Nasional yang mengatur, selain eksistensi masing-masing, juga mengatur kewenangan, kewajiban, tugas, fungsi dan proses atau prosedur dalam penanganan korupsi di Indonesia.

\section{3) Pengawasan dan Pengembangan}

Kualitas interaksi yang baik akan melahirkan kemampuan sistem dalam melakukan pengawasan (self-control), kemampuan produksi (self-production) dan pengembangan (self development). Hal ini hanya tercipta melalui pola interaksi yang didasarkan atas prinsip-prinsip kerjasama atau koordinatif, atau prinsip-prinsip lain yang memiliki keberterimaan di antara semua pilar kelembagaan sesuai 
kapasitas, fungsi dan profesionalitas masing-masing, seperti kebenaran, kejujuran, dan kepercayaan.

Implikasi dengan dibangunnya Sistem Integritas, tidak ada lagi tumpang tindih kewenangan penyidikan di antara kejaksaan, kepolisian dan KPK dalam pemberantasan korupsi. Hal ini disebabkan Sistem Integritas menempatkan ketiga lembaga penegak hukum tersebut yang kedudukan dan kewenangan yang sama dan independen. Visualisasi prinsip koherensi dalam pembentukan fondasi normatif misalnya dengan membentuk Mahkamah Integritas yang bertanggungjawab membentuk fondasi normatif agar Sistem Integritas dapat dijalankan pada lingkup Kejaksaan, Kepolisian dan KPK. Sementara itu visualisasi mekanisme kerja kelembagaan dalam sistem integritas, ketiga lembaga akan bekerja sama dalam melakukan penyidikan tindak pidana korupsi dengan batasbatas kewenangan yang ditetapkan oleh Mahkamah Integritas. Tidak ada lagi tumpang tindih dan merasa lebih tinggi dan lebih penting dari yang lainnya.

\section{Penutup}

Berdasarkan pembahasan yang telah dikemukakan di atas, maka dapat disimpulkan hal-hal sebagai berikut: Pertama, sistem pemberantasan tindak pidana korupsi dalam hukum positif Indonesia saat ini (ius constitutum) yang menempatkan KPK sebagai leader, masih menimbulkan ketidakharmonisan antara para penegak hukum. Hal ini menunjukkan strategi pemberantasan korupsi di Indonesia saat ini masih belum efektif dan belum optimal; Kedua, strategi pemerintah Indonesia untuk memberantas korupsi di masa yang akan datang (ius constituendum) dapat dilakukan melalui sistem integritas pada lingkup KPK, Kepolisian dan Kejaksaan yang menempatkan ketiganya sebagai aparat penegak hukum dalam pemberantasan korupsi yang mempunyai kedudukan dan kewenangan yang sama, saling bersinergi satu sama lainnya dalam pemberantasan korupsi; Ketiga, konsep Sistem Integritas tindak pidana korupsi dalam penyidikan yang dilakukan oleh Kejaksaan, Kepolisian dan KPK dilakukan dengan upaya meningkatkan manajemen pengawasan, selanjutnya membentuk Mahkamah Integritas di ketiga lembaga tersebut. Sistem integritas pada lingkungan Kejaksaan, Kepolisian dan KPK harus bisa memposisikan ketiga lembaga ini menjadi Badan 
Anti Korupsi yang independen. Sistem integritas ini menekankan adanya check and balances antara lembaga penegak hukum karena bertindak sekaligus yaitu sebagai pengawas dan yang diawasi, sebagai pemantau dan yang dipantau, sehingga terbentuk suatu lingkaran kebajikan yang merupakan suatu bentuk tanggung gugat (akuntabilitas) horizontal, di mana para pihak bertanggung jawab kepada pihak lainnya secara horizontal bukan bertanggungjawab ke atas dalam struktur hierarki yang mengerucut.

Adapun saran-saran yang dapat dikemukakan adalah sebagai berikut: Pertama, agar pemberantasan korupsi di Indonesia dapat berjalan konsisten perlu adanya koordinasi yang baik antara Kepolisian, Kejaksaan dan KPK. Selain itu perlu ditingkatkan SDM berupa peningkatan pendidikan yang lebih tinggi. Kedua, pemerintah dan DPR disarankan segera merevisi Undang-Undang Nomor 30 Tahun 2002 tentang Komisi Pemberantasanan Tindak Pidana Korupsi dan Undang-Undang lain yang mengatur tentang penyidikan dan penuntutan korupsi dengan tujuan untuk memperkuat penanganan pemberantasan tindak pidana korupsi guna memperkuat komitmen independensi, profesional, dan akuntabel. Ketiga, terkait dengan sistem integritas disarankan agar ditambahkan budaya hukum dalam upaya pemberantasan tindak pidana korupsi sesuai dengan aturan yang berlaku dan ditumbuhkan ketauladanan dari pejabat negara dimulai dari presiden, pejabat penyelenggara negara dan aparat penegak hukum itu sendiri. Dalam mengembangkan budaya malu, pelaku tindak pidana korupsi perlu ditayangkan wajah koruptor di media massa, dengan demikian sistem integritas akan didukung oleh semua komponen bangsa dan aparat penegak hukum yang berintegritas. Keempat, pembangunan pola sistem integritas antara Kejaksaan, Kepolisian dan KPK juga dilakukan dengan jalan membuat skema integritas dalam melakukan penyidikan yang melibatkan aparat penegak hukum dari masingmasing institusi. Pengungkapan suatu kasus tindak pidana korupsi yang melibatkan aparat penegak hukum dari salah satu institusi tidak lagi ditangani oleh instansi asal, namun ditangani oleh instansi lainnya, yang pada akhirnya akan terpola sebagai lingkaran kebajikan dengan masing-masing instansi yang mempunyai peran sekaligus yaitu sebagai pihak yang mengawasi dan yang diawasi, sebagai pihak yang memantau dan yang dipantau. 


\section{Daftar Pustaka}

\section{Buku:}

Assegal, Ibrahim S., A Gloomy Picture of the Attempts to Eradicate Corruption: Reflection of the Policies, Laws and Institutions of Corruption Management in Indonesia, 1969-2001, In Richard Holloway, Stealing from the People, 2012.

Friedman, Lawrence M., A History of American Law, Simon and Schuster, New York, 2013.

Hage, Jaap, Studies in Legal Logic, Law and Philosophy Library, Springer, Meta-juridica Department, University of Maastricht, 2011.

Marzuki, Peter Mahmud, Penelitian Hukum, Kencana Prenida Media, Jakarta, 2011.

Soekanto, Soerjono, Pengantar Penelitian Hukum, Universitas Indonesia Press, Jakarta, 2006.

Soemitro, Ronny Hanitijo, Metode Penelitian Hukum dan Jurumetri, Ghalia Indonesia, Jakarta, 2008.

Waluyo, Bambang, Penelitian Hukum Dalam Praktik, Penerbit Sinar Grafika, Jakarta, 2001.

\section{Makalah/Jurnal:}

Agustina, Gemalia, "Pemahaman Strukturasi atas Praktik Audit Investigatif pada Kantor Perwakilan BPK-RI di Surabaya (Studi Kasus Tindak Pidana Korupsi)", Jurnal Ekonomi dan Bisnis, Vol. 8, No. 3, 2010.

Fazzan, "Korupsi di Indonesia dalam Perspektif Hukum Pidana Islam", Jurnal Ilmiah ISLAM FUTURA, Volume 14, No.2, 2015.

Haq, Hayyan ul, "Legal Instruments for an Optimal Utilization of Information and Technology Under the Intellectual Property Regime: A Study on the Implication of the Creator and Inventor Doctrine for the Utilization of Intellectual Products Through Technology Transfer for the Greatest Benefit of People in Indonesia", Disertasi Ph.D, Utrecht University, The Netherlands, 2011.

, "Strengthening Philosopical and Axiological Legal Framework of the Corporate Sosial Responsbility Regime in Indonesia", in Tineke Lambooy, et.al., Corporate Sosial Responsbility, Konstitute, Jakarta, 2013.

Koesoemo, Cindy Rizka Tirzani, "Eksistensi Komisi Pemberantasan Korupsi (KPK) dalam Penanganan Penyidikan dan Penuntutan Tindak Pidana Korupsi", Lex Crimen Vol. VI, No. 1, 2017.

Laksmana, Ganjar, "Partisipasi Aktif Publik dalam Pencegahan dan Pemberantasan Korupsi" Pusat Penelitian dan Pengembangan Sistem Hukum Nasional Badan Pembinaan Hukum Nasional Kementerian Hukum dan Hak Asasi Manusia R.I., 2015. 
Niasa, La, "Corruption Eradication In The Perspective Of Criminology", International Journal of Scientific E Technology Research, Volume 5, No. 07, 2016.

Powell, Mel D., "International Efforts to Combat Corruption" Prociding of 2017 Annual Conference American Society for Public Administration Atlanta, Georgia, Vol.17, No. 21, 2017.

Rachman A., Abd., "Policy Analysis and Educational Strategy For Anti Corruption In Indonesia and Singapore", International Journal of Asian Social Science, Vol. 5, No. 11, 2015.

Rahadian, A. H., "Sistem Integritas Nasional sebagai Kebijakan Mencegah dan Memberantas Korupsi di Indonesia", Prosiding Seminar STIAMI, Volume I, No. 02, 2014.

Shiddiqy, Rizky Aji, “Membangun Zona Integritas Sebagai Upaya Pemberantasan Korupsi", Fakultas Ekonomi dan Bisnis, Universitas Brawijaya, 2015.

Winarno, Muhammad, "Sistem Integritas Nasional", Pusat Pengembangan Tenaga Pendidik (Pusbangtendik) Kementerian Pendidikan dan Kebudayaan (Kemdikbud), 2015.

\section{Peraturan Perundang-Undangan:}

Undang-Undang Dasar Negara Republik Indonesia Tahun 1945.

Kitab Undang-Undang Hukum Acara Pidana

Undang-Undang Nomor 28 Tahun 1999 tentang Penyelenggara Negara yang Bersih dan Bebas Korupsi.

Undang-Undang Nomor 48 Tahun 2009 tentang Kekuasaan Kehakiman.

Undang-Undang Nomor 2 Tahun 2002 tentang Kepolisian Republik Indonesia.

Undang-Undang Nomor 16 Tahun 2004 tentang Kejaksaan Republik Indonesia.

Undang-Undang Nomor 46 Tahun 2009 tentang Pengadilan Tindak Pidana Korupsi.

Undang-Undang Nomor 31 Tahun 1999 jo Undang-Undang Nomor 20 Tahun 2001 tentang Pemberantasan Tindak Pidana Korupsi.

Undang-Undang Nomor 12 Tahun 2011 tentang Pembentukan Peraturan Perundang-Undangan.

Undang-Undang Nomor 10 Tahun 2015 tentang Penetapan Peraturan Pemerintah Pengganti Undang-Undang Nomor 1 Tahun 2015 tentang Perubahan Atas Undang-Undang Nomor 30 Tahun 2002 tentang Komisi Pemberantasan Tindak Pidana Korupsi Menjadi Undang-Undang. 